\title{
繊維・染色用ゴム製品
}

\section{井上寿 一*}

\section{1.はじめに}

䋐維・衣料用ゴム製品について，その現状及び問題 点，要望事項を奇稿するよ5依賴されたが，もとより筆 者自身その任には極めて不適当の者であり，社内紡織工 務部及び染色工務部から資料の提供を受けてそれを継ぎ 合わせたような結果になったことを前もっておわぴする 次第である。京た染色仕上用ゴムロールについては金陽 社の山田泰之助氏に種々ご助言並びに資料提供を受けた ことを報告するとともに併せて鹊意を表したい，

緎維・衣料用に使用されているゴム製品は多種多様で あるので，ここでは対象を絞って紡織関係ではゴムコッ ト，ゴムエプロン，染色仕上関係ではゴムロールについ て説明する。

\section{2. 紡績ゴムコットとゴムエプロン}

ゴムコットとゴムエプロンは，いずれも紡績糸を得る 際に，杀のドラフトを行うためのものであり，その構造 は図1のよ5になっている.

ゴムコット及ぴエプロンは最初革製品が使用されてい たが，戦後になってこれらをゴム製品に変える努力がな された.しかし天然ゴムは耐油性に欠けるなどの理由に より失敗に終わり，合成ゴム，殊にニトリルゴム(NBR) を使用することによって初めて成功した．合成ゴムの利 点はライニングと研磨が容易であり，均質性むよく，崩 壊しにくいなどが挙げられる，したがって合成ゴムの場 合にはほとんど注意を払らことなく長期にわたって使用 できるし，また再研磨すれば簡単に再生することもでき る.

戦後，紡機のほうも多くの改良が加えられ，高速化， ハイドラフト, 高加重, 新しい合繊の登場, 更に空調と ニューマクリヤラーによる空気流の增大といらような操 業条件の変化を見るに至り，エプロンやコットに要求さ

\footnotetext{
* 東洋紡績株式会社研究開発部

(要530 大阪市北区堂息浜通 2-8)
}

れる性筫も一層大きく皦しくなっていった.

表 1 にゴムエプロンとゴムコットについて要求される 条件を示す.

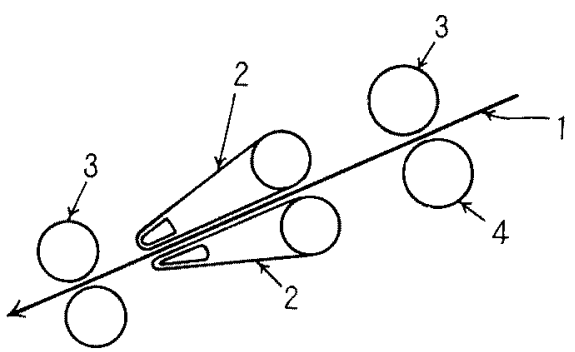

$1:$ 米, 2 : エプロン, $3:$ コット, 4 : スチール フルーテッドローラー

図 1 ゴムコットとゴムエプロンの構図

表 1 エプロン，コットに要求される条件

\begin{tabular}{|c|c|}
\hline 機械的・化学的条件 & 正常ドラフトにおける条件 \\
\hline 耐油耐グリース & 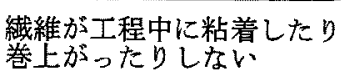 \\
\hline 耐経年変化が少ない & 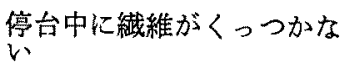 \\
\hline $\begin{array}{l}\text { オゾンによるぜい化ひび割 } \\
\text { れがない }\end{array}$ & 纎維がフェルト化しない \\
\hline 充分な引張に耐える & 凝結しない \\
\hline 破填を起こさない & 温湿度の変化に耐える \\
\hline 正常な硬度にある & 正常な摩擦力 \\
\hline 適正な接着力 & 制電性 \\
\hline 寸法安定性 & ひずみがない \\
\hline $\begin{array}{l}\text { 〈ぼみに対して速やかに復 } \\
\text { 元する }\end{array}$ & 円周の真円性 \\
\hline \multicolumn{2}{|l|}{ 完全な操作性 } \\
\hline 寿命が長い & 強い均斉な杀 \\
\hline 保全に手がかからない & 杀切率が小さい \\
\hline 価格が安い & 労働生産性が高い \\
\hline
\end{tabular}


機械的精度は非常に高度のものが要求され，例えばコ ム・コットの場合, $0.013 \mathrm{~m} \mathrm{~m}$ 以上の偏心があってはなら ないし, エプロンの場合, 直径 $50 \mathrm{~mm}$ mざは, その直径 で $00.015 \mathrm{~mm}$ 以上の誤差は許されない.

機能的条件としては，繊維の潤滑や機械の注油の関係 から耐油性が必要である。必た選転中静電気の発生によ り糸が巻き付くのを防ぐために制電性を付与することが 必要である，更に静電気の放電によりオン゙ンを発生する のでオゾンによるひび割れの抵抗性も必要である．更に エプロンでは伸びと切断に対する抵抗性も重要であり， コットの場合には基台ロールとの充分な接着性も重要で ある。コットの硬度は $65 \sim 85^{\circ} \mathrm{BS}$ が一般に用いられ，細 番手の系には柔らかいものを，合絨又はそ（梳）毛用に は硬いるのを使用する．また運転を停止している間にフ ルーテッドローラーのマークがコットにつかないように 急速な復元力が必要である.

上述のよ5な多くの要求をひとつの材料によって満足 させることは極めて難しいが，合成ゴムの場 合，基 ゴ

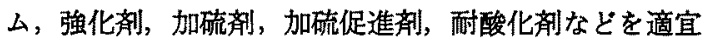
選択組合わせることによって種ヶの性質を付与すること ができるので有利である，最近はコットあるいはエプロ
ンの表面を処理刜で処理したり，紫外線照射して表面を 改㓋し，耐油污れ性，耐オゾン少化性を改良することも 行われているが，有害な処理刜で処理することは公害の 原因になりやすいのでゴム自体の改質が望まれる，

なお合成ゴムのコットあるいはエプロンとして必要な

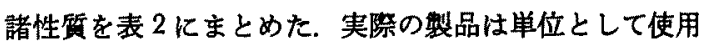
しないので表 2 に示した性質を適宣勘案して配合する。

表 2 において耐油性と耐オソン性は評価 3 以上が必要 である。

最近，ゴムに代わってポリウレタン系合成皮革のエプ ロンなどが出てきており，ゴムと競合しつつある。

\section{3. 染色仕上げ用ゴムロール}

染色仕上げに使用されているゴムロールは単に布又は 系を誘導するためのガイドロールから絞りロール，パッ ディングロールのような商度の機能を要求されるロール まで多種多様であり，その使用態様も多岐にわたってい るが，ここでは特に絞りロール，パッディングロールを 中心に話を進めたい.

\section{1 染色仕上げ工程}

染色仕上に適用される工程は極めてバラエティに富ん

表 2 ゴムの性質比較表"

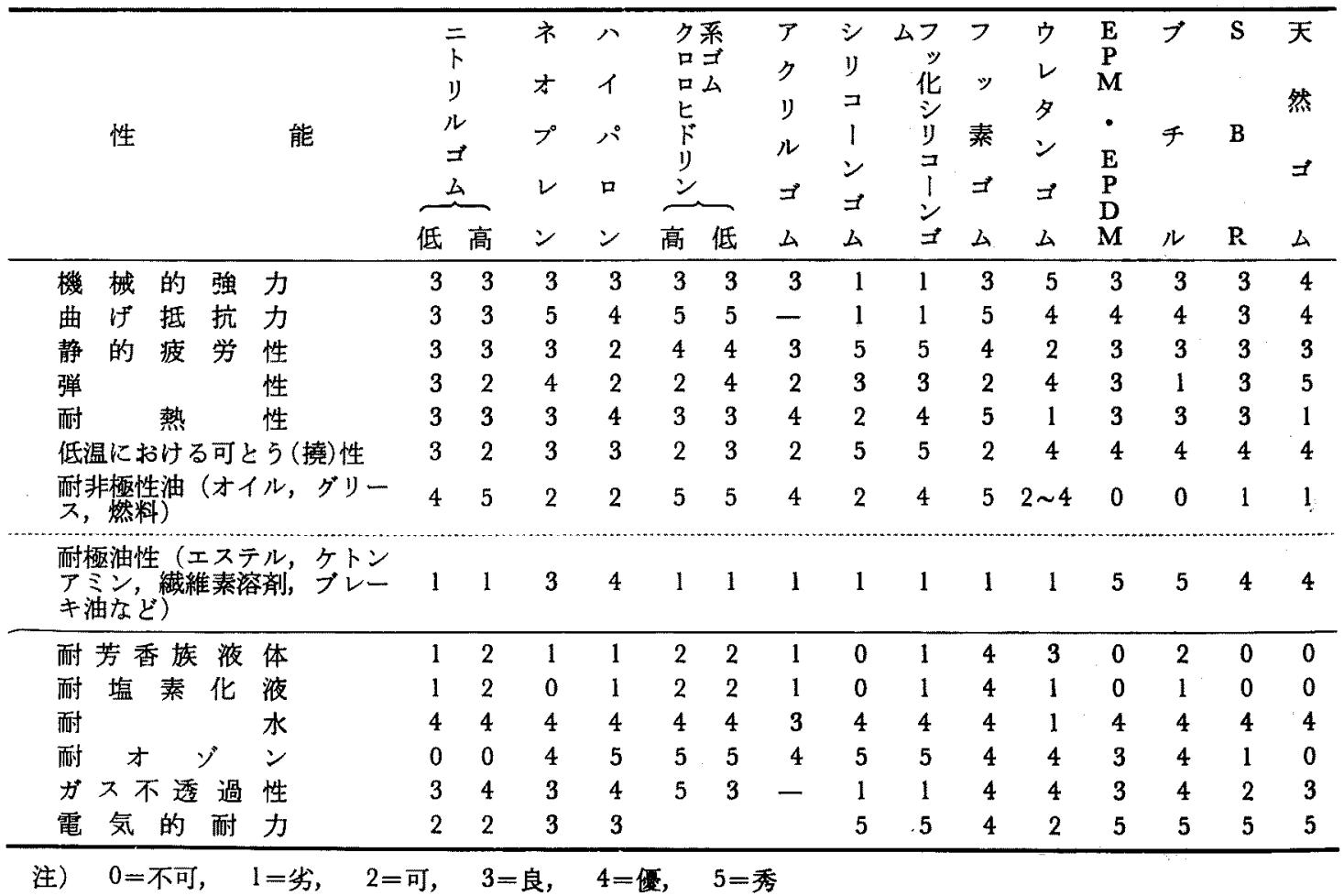


でいる.ごく简単にその工程の概要を磁明すると次のよ らになる。

布はく（帛）の染色仕上げ工程

1)のり掖き 布を織る際，経糸にデンプン，PVAな どを主凨とするのりを付けるので，これをます除去 する作業をする、これにはアミラーゼ，すなわちテ ンプン分解䤃素や酸化剂が使用される.

2)精練 綿のような天然緎維では不純物を除去し, 水 などの浸透性をよくするため $3 \%$ ～ $5 \%$ のカ性ソー ダ水溶液を用いて $100^{\circ} \mathrm{C}$ 付近で処理する.

合成繊維 $100 \%$ の布はくでは上述のよ5な工程は必 要ないが, 綿・合成繊維の混合品ではやはりカ性ン 一ダ処理が必要である，最近ではトリクレン，パー クレンのよ5な溶剂で精練することも開発されつつ ある。

3)漂白 布はくを白くするために過酸化水素，カルキ などの酸化剂水溶液で漂白する，最近は特に綿・合 成䄉維の混合品について亜壏素酸ソーダ水溶液を用 いて $100^{\circ} \mathrm{C}$ 付近で加熱処理し, 精練と漂白の両工程を 同時に行ってしまうことが多くなっている.

4)染色 染色法は染料の種類によって大きく相違す る. 使用する薬液としては染料のほかに酸（硫酸， 酢酸，キ酸)，アルカリ(カ性ソーダ，炭酸ソーダ)， 酸化剂（過酸化水素など），還元凧（ロンガリット， 酸性亚硫酸ソーダ)，種心の界面活性成，キャリヤー （染色促進㶡，フェノール系のものが多い）などが 適宜混合使用され，染色法は $100^{\circ} \mathrm{C}$ 又はれれ上の高 温の液中で染色する浸染法，布を染液中に浸せきし た後ゴムロールで絞り，その後 $120^{\circ} \mathrm{C} \sim 180^{\circ} \mathrm{C}$ で乾熱 処理又は蒸熱処理するいわゆるパッディング法など がある。

5)仕上防しわ，防縮，带電防止，防水，発水などの いわゆる改僙加工があり，これは上述の上らなパッ ディング法が多く用いられる。このほかカレンダー によるつや出し加工，布幅をそるえ，風合を調節す るためののり付け，幅出し加工などがある。

6)マーセライズ加工この工程は通常上記精練又は漂 白工程の前又は後に行う工程であって, 20 30\%力 性ソーダ水溶液に綿又は綿・合成繊維混合品を浸し し，㗨張状態で処理することによって独得の光沢と 寸法安定性を得るものである。

布はくの染色仕上工程をごく隔単に説明したが，今後 は更に公害防止の見地から溶剂精練，溶剂染色のような トリクレン，パークレン，アルコールなどの有機溶刜を
使用する染色，仕上げ法が增加するであろ5。

\section{2 染色仕上け用ゴムロールに要求される睹性而}

前述のよ5に染色仕上げには多くの薬成が使用され， 処理温度も商く，またゴムロールは紻維製品を絞ること に多く使用されるところから，染色仕上用ゴムロールに は耐薬品性，耐圧性，酎摩耗性，耐熱性が要求され，通 常これら諸性質の2つ以上が同時に必要となる。

3.2 .1 耐アルカリ性 前述のよ5にマーセライズ加 工を初めとして染色仕上工程においてコムロールが高涶 度のアルカリに触れることは多い，一般にゴムそのもの はアルカリに対して抵抗性があるが，配合風の5ちには アルカリによって分解されるものがあり，これが耐アル カリ性低下の原因になるので，この点を考慮した耐アル カリ性配合が必要である。

3.2 .2 酎酸化洞性 前述のよ5に漂白工程では過酸 化水素，西塩素酸ソーダのよ5な酸化凪が使用され，染 色でも同様に酸化剂が使用されることがある，ところが 天然ゴム、ニトリルゴム，クロロプレンゴムのような一 般用ゴムは激しく酸化作用を受け使用に耐えない，ハイ パロンのような分子中に二重結合を持たないゴムであっ ても高温での酸化条件になると粘着性を带びる。したが ってこのような工程では樹脂加硫ブチルゴムのような耐 酸化性のゴムを使用することが必要であり，この点今後 の改良に待つところ大である。

3.2 .3 耐活性剂性 染色仕上工程では各所で界面活 性剂が浸透剤，分散剤，柔軟肪，带電防止剤などとして 広く使用されている，その使用量は多くはないがゴムに 対する影響は無視できない，温度が高くなれば一層速や かに影響は大きくなり，膨潤，軟化，表面凹凸発生など の現象を起こす，表 1 は原料ゴム(基本配合の各種油鼡) に対する浸せき試験結果である。

表1からわかるよらにいずれのゴムに詨してもかなり の影響が認かられる. しかし，配合をくふらすることに よって影響をかなり小さくすることができるという。

3.2 .4 耐溶剂性 有機溶荗はこれまでも染色の際の 助俞として使用されてはいたが量が少ないのでゴムロー ルへの影帮は比較的少なかっった。かし今後はトリクレ ン，パークレンのよ5な溶剂の液そのbのを使用した処 理法が增加することを考えるとゴムロールにとっては大 問題である. ジムはその化学構造からしても有機溶剤に 侵されやすいものであり，検討を要するところである，

3.2 .5 酎磨耗性 ゴムの耐摩耗性は原料ゴムの種類 と配合剤によって充分に改善できるようになったが，薬 品によって劣化されている場合，あるいは駆動の方式や 
表 3 各種ゴムの耐界面活性剂性 ${ }^{2)}$

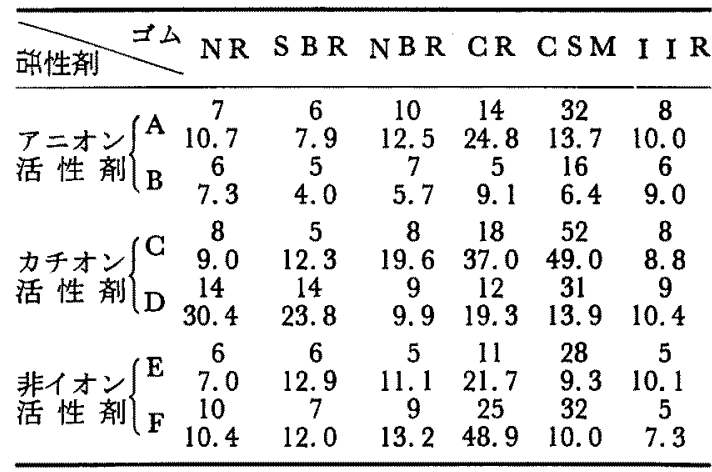

注）浸せき条件 $10 \%$ 水溶液， $80^{\circ} \mathrm{C} \quad 168$ 時間

[わく内上段数字は硬度低下，下段数字は吸収\%] 活性剂A……ひまし油の低度硫酸化油

" B B.....高級アルコール硫酸エステル塩

" G……高級アルキルアミンの無機酸塩

"D D.....脂肪族第 4 級アンモニウム塩

" E……ํリエチレングリコール高級脂肪酸エステ ル

" F F ……ポリエチレングリコール高級アルコールエ ーテル
荷重のかかり具合によってゴムが局部的に摩寜される場 合には摩耗される場合があるから注意を要する

3.2 .6 耐压性 ヨ゙ムに繰返し変形を与えると急激に 軟化し，ついには破壊することがある。コムロールで布 はくを絞る場合にはちょらどこれと同じ状態になるの で注意を要する．ゴムの疲労性は充てん剂の種類と配合 量, ゴムの弾性に関倸があり，ポリブタジエンの上らな 高弾性のゴムが耐疲労性に優れている、コムムロールで絞 る場合にかかる荷重は通常 $30 \sim 50 \mathrm{~kg} / \mathrm{cm}$ 程度であるが， これ以上の高荷重で使用することもあり，80 kg/ $\mathrm{cm}$ 以上 の荷重の場合はゴムの耐圧性を充分考虑する必要があ 万.

\section{引用文 献}

1) D. G. Turner: Textile Institute and Industry. 8, $9,(1970)$

2）山两泰之：染色整理用ゴムロール，p. 11，日本 瀻維機械学会 (1968)
H801066

\section{ダラス空港の実験用 Airtrans}

Dallas-Fort Worth's Airtrans: model for future PRT systems

新しい輸送方式である Airtrans として知られている システムが，最近米国の Dallas-Fort Worth 架港で使わ れた。 これは小さなゴムタイヤがコンクリートのガイド ウェ一の上を走る乗物で，旅客，従業員，郵便，荷物， くずなどを，雕れた旅客ターミナルの間を運んで扣り， 完全自動化により，コストダウンを計っている。

この空港は，非常に広いので，旅客と荷物を運ぶため に，この方式を採用した，毎時 9000 人，6000の荷物， $7000 \mathrm{lb}$ の郵便物を運泉。

51 両の客車と17両の業務用車があり， 1 両か 2 両で運 転されている。客車は長さ $21 \mathrm{ft}$, 幅 $7 \mathrm{ft}$, 高さ $10 \mathrm{ft}$ で, 空車で重量 $14,000 l b$ である。車体は，積層アクリルで 表面をガラス繊維で括抏ってある，1两に40人乗れる。 走行用動力は，A C480Vで,制御用は，D G48Vである. この A C 電源は, 整流器を通して, D C60 HP モタを 駆動している，最高速度は，毎時 17 mile で，A C電源は， 電熱器や空気調和や空気の供給に使われている，貨物用 コンテナはアルミの台わく上に乗せられたガラス布でお おわれた合板製のもので，179個ある.
ガイドウェーはコンクリート製で両側に側壁がある。

転てつ萃置はLTV 社により新しく開発されたもの で，基本的にはガイドウェーの側壁に取付けた可動羽根 からなる。転てつを行なうには，この羽根が自動転てっ 機によって車両の操絽機構に取付けた小車をとらえる位 置に動かす。

Airtrans はすべて自動運転で，運行費を下げ，経済的 にも貢献している，中央制御室では，運行のすべてが監 視されていて，すべての車両の位置や状態は，連続的に ガイドウェーの略図上に，ランプで示されている，中央 のオペレータは，車を減速したり，分吱やルートを変え たり，駅の通過等を制卸する。

駅は53あって，旅客用，従業員用，荷物と郵便用に分 かれている.これらの駅を回るには17の異なったルート がある. 乗客は最も近い駅の位置を決めるために，表示 を調べる．駅までの道は入口の回転扉の中にある方向板 によりわかる。その内側には道順を示才表示と地図がつ いている。乗車時閒は待ち時間ともで平均 $8 \mathrm{~min}$ で，最 大20min 以下である。

将来は Airtrans 㳊改良され拡大されるであろ5，他 の空港ターミナルができたとき，もっとガイドウェーや 駅が増設されて，空港とその周りの都市が一つに結ばれ るであろら，写図 5

ELLIOTT DM B 282 Civil Eng 44 ( 7) 70-73('74) [日本科学技術情報女 ンター発行「海外技術ハイライト」より轻载許可第165号] 